\title{
Effects of blended versus offline case-centered learning on academic performance and critical thinking ability among undergraduate nursing students】a cluster randomized controlled trial
}

\section{Zhenzhen Yu}

Fujian Medical University https://orcid.org/0000-0001-6989-8574

Ling Shen

Fujian Medical University

Jiayuan Zhuang

Fujian Medical University

Yimin Chen

Fujian Medical University

Meijing Chen

Fujian Medical University

Yazhu Lin

Fujian Medical University

Rong Hu ( $\nabla$ ronghu1246@fjmu.edu.cn )

https://orcid.org/0000-0002-3039-0498

Research article

Keywords: education, nursing, teaching methods, critical thinking

Posted Date: April 20th, 2020

DOI: https://doi.org/10.21203/rs.2.14460/v4

License: (c) (1) This work is licensed under a Creative Commons Attribution 4.0 International License. Read Full License 


\section{Abstract}

Background: Educational reform, especially methods of teaching, has been a focus among nursing educators. This study explored the impact of blended versus offline case-centered learning on academic performance of Medical Nursing and critical thinking ability among undergraduate nursing students.

Methods: A cluster randomized controlled study design was used, with assessments immediately before and one school year after the intervention. All the second-year undergraduate nursing students in two class were enrolled in this study by cluster sampling. The two classes of Medical Nursing were randomly allocated to either the experimental class, which undertook blended case-centered learning, or the control class, which undertook offline case-centered learning. The primary outcomes were academic performance consisting of final exam and process assessment, as well as the critical thinking ability assessed with the Critical Thinking Disposition Inventory-Chinese Version (CTDI-CV). The Mann-Whitney U test and the unpaired t test was subsequently used. ANCOVA analyses were also performed to examine the two teaching methods' effect on academic performance and critical thinking.

Results: Students in the experimental class showed a significantly higher improvement in academic performance of Medical Nursing than the control class. In addition, compared with the control class, the pre-post difference in competency in critical thinking self-confidence in the experimental class was significantly greater $(p=0.037)$. In the experimental class, there was significant improvement compared with baseline in dimension of critical thinking self-confidence $(p=0.022)$. In the control class, there was significant improvement compared with baseline in the total score $(p=0.029)$ and two of the seven dimensions: truth-seeking $(p=0.016)$ and systematicity $(p=0.005)$.

Conclusions: Use of the blended case-centered learning showed the promising results in promoting students' academic performance. Both the blended and offline case-centered learning in this study were a suitable educational approach to improve the critical thinking ability of undergraduate nursing students. In the future, blended and offline case-centered learning could be implemented in other nursing subjects. Moreover, further efforts to improve teaching are warranted.

\section{Background}

\section{Nursing educational reform is needed to increase the quality of teaching}

With the development of the social economy and the transition to the modern medical model and concept of health, developing comprehensive high-quality skills among nursing personnel is increasingly important. However, nowadays, much of nursing pedagogy relies on a traditional didactic approach that focuses on passive lecture-based delivery of content, leaving the students as passive participants who largely only take notes. Using this method, students do not have the opportunity to engage in contemplation, which is necessary during the learning process. In order to provide effective and efficient education for nursing students, calls to change traditional educational strategies are of increasing importance. 
The goals of university nursing education are to teach theoretical knowledge, as well as develop the ability of students to critically analyze evidence [1]. Critical thinking is an important component of nursing education and integral to the discipline of nursing [2,3]. Critical thinking is an essential professional development core skill in nursing education and practice [4]. Worldwide, there is a need for nursing education to assist students in developing critical thinking, clinical reasoning, and clinical judgment skills [5]. Educational reform, especially regarding methods of teaching, has been a focus among nursing educators.

\section{Case-based learning and the flipped classroom are feasible in nursing curricula}

Active learning strategies applied to nursing education can enhance students' understanding, stimulate inquiry, and encourage critical thinking [6]. To best attract students and promote learning, there has been a shift toward student-centered learning and engagement of students as active learners. Case-based learning (CBL) is an instructional method within the context of student-centered learning for facilitating learning through the use of case studies [7]. It is a long-established pedagogical method that is defined in a number of ways depending on the discipline and type of "case" employed [8]. McLean's definition of $\mathrm{CBL}$ is "an inquiry structured learning utilizing live or simulated patient cases to solve, or examine a clinical problem, with the guidance of a teacher and stated learning objectives" [9]. In nursing education, $\mathrm{CBL}$ can be applied to preparing students for clinical practice through the use of authentic clinical cases $[10,11]$ and increase their capacity to ask questions, reflect, and deal with problems $[12,13]$. Previous research has indicated that $\mathrm{CBL}$ is a more effective technique than traditional didactic lectures for improving communication skills, problem-solving ability, and motivation in undergraduate nursing students $[14,15]$. In addition, the advantages of using CBL include increased focus on learning objectives, flexibility in the use of the cases, opportunity for the teacher to have more input toward the direction of learning, and enabling deeper learning. Owing to these benefits, CBL is likely to become part of numerous curricula for medical and health professional courses [9].

In addition to $\mathrm{CBL}$, flipped classroom pedagogy has attracted the attention of educators and has been widely implemented and studied in many disciplines, including nursing [16-19]. Some studies have found that the strategy of flipped classroom in nursing education presents certain advantages over traditional lecture-based learning in terms of improving students' examination scores, grades and satisfaction [20, 21]. Conversely, some studies showed the flipped classroom not to be superior to traditional models with respect to student examination scores and satisfaction [22, 23]. A meta-analysis on the effects of the flipped classroom model among Chinese baccalaureate nursing students showed that flipped classrooms are more effective than traditional lectures at improving students' theoretical knowledge and skills [24].

\section{Blended approaches have become more prevalent in the information age}

Nowadays, technological advancements are rapidly changing nursing education in higher education settings. This has led to a push toward flexible delivery, online delivery, and blended learning. Blended learning refers to an educational approach that combines traditional classroom-based face-to-face 
teaching methods with online materials and activities [25]. Garrison and Kanuka, early promoters of the blended learning approach, have highlighted several advantages of blended learning [26]. They describe blended learning as having the potential to transform the educational landscape by giving students more responsibility, control, and independence, while also increasing their capacities for critical and reflective thinking.

Blended learning is considered crucial for the education of today's health students [27]. In recent years, blended learning has been used in nursing and medicine, and many studies have been conducted in this area [28-32]. However, the implementation of blended learning in nursing education remains controversial. Some investigations have shown that blended learning is favored by undergraduate nursing students, facilitates communication and active learning, and enhances self-efficacy regarding communication skills [33-35]. On the other hand, one study did not find a direct impact on knowledge acquisition or self-learning readiness [31]. Another study did not show differences regarding overall satisfaction with the teaching received [28]. Hence, there is concern regarding the outcomes associated with this method.

Although blended learning has been extensively used, there is limited knowledge regarding the effective application of blended learning based on CBL in nursing curricula to support critical thinking [34, 36]. Therefore, the main objective of this study was to compare blended and offline learning (both based on case-centered learning) on academic performance and critical thinking ability among undergraduate nursing students.

\section{Methods}

\section{Design}

This study used a cluster randomized controlled study design with pretest and posttest assessments undertaken immediately before the intervention and 1 school year after the intervention, respectively.

The students were randomly assigned by Zhengfang software (Zhengfang Corp., West Lake District, Hangzhou, China) to two classes when they entered the university. Class 1 had 164 students with eight groups, while Class 2 had 131 students with seven groups. Each group consisted of approximately 20 students. Thus, the randomization in this study occurred at the class level. An administrator employed by the university, who had no information regarding the recruitment or data collection, conducted the random allocation. Two labels (numbered 1 and 2) were placed in opaque envelopes, and the administrator then requested one of the Medical Nursing teachers to selected one envelope at random. As "number 1" was selected, class 1 was to be the experimental class while class 2 was to be the control class.

\section{Samples and setting}


Cluster sampling was used and the sample comprised all the second-year undergraduate nursing students starting the Medical Nursing course in the fourth semester at the Nursing School of Fujian Medical University (Fuzhou, China). Students who changed majors or discontinued the course or had no desire to participate in the research were excluded in result analysis.

\section{Intervention}

\section{Teaching arrangements}

The Medical Nursing course was conducted for 1 academic year, in the fourth and fifth semesters, and it involved 144 teaching hours and 8 credits, which is the highest number of credits of all undergraduate nursing courses.

The learning objectives of the Medical Nursing course are: (i) to master the theoretical knowledge of this course; (ii) to improve students' capability regarding holistic nursing; (iii) to equip students with the ability to analyze and solve problems as well as the ability of clinical reasoning and critical thinking; (iv) to cultivate nursing students' professional ethics. Twelve teachers took part in teaching Medical Nursing. All of them underwent the same training regarding the specific processes of blended learning and offline case-centered learning. In addition, collective lesson preparation (involving all the teachers) was conducted before teaching each chapter in order to guarantee high-quality teaching.

The study was conducted between September 2018 and July 2019. The same teachers, textbook, and references were provided to both groups. All teaching materials of flipped classroom and cases of seminars for the control groups were discussed and decided in collective preparation meetings by the teaching team of Medical Nursing The experimental class underwent blended case-centered learning including online and offline learning, whereas the control class totally underwent offline case-centered learning (Table 1). Notably, whether in lectures, flipped classrooms, or seminars, the teaching method involved case-based learning. Although blinding of the students and teachers was not possible, the data analyst was blinded.

\section{Experimental class}

Apart from traditional face-to-face lectures in class, there were three stages in the implementation of the blended case-centered learning, comprising before, in, and after each flipped classroom (Figure 2).

Before the flipped classroom, all students were required to log in the Chaoxing platform (http://i.mooc.chaoxing.com/space/index.shtml) to watch the pre-recorded lecture videos and access the online forums and study materials. Besides, group cases study was also required and necessary. Students subsequently divided into 4 subgroups (approximately five students per subgroup) to discuss the cases and the questions that the teacher provided prior to the class, recording the whole process of their discussion and producing a report. Each flipped classroom involved one group, with approximately 20 students, and they were divided into four subgroups based on the pre-class group discussions. To assess the students' mastery of the lesson prior to class, online quizzes, which lasted approximately 10 
minutes, were performed at the beginning of the flipped classroom. Subsequently, the teacher provided detailed explanations of the quiz questions according to the students' results, then the students reported what they had discussed prior to class. Next, other classmates provided supplementary answers and questions. The teacher commented on each report, summarized and guided the students to think and discuss. After the flipped classroom, the students were requested to submit homework to the platform, raise questions in the online forums or review teaching videos. All study data were recorded via the platform and could be accessed by the teachers.

\section{Control class}

The control class underwent offline case-centered learning via traditional face-to-face lectures and seminars throughout the two semesters (Figure 3). Before the seminar, the students were required to preview the textbook. Each seminar involved one group, with approximately 20 students. During each seminar, students formed 4 subgroups to discuss the cases under the guidance of the teacher. Subsequently, the teacher randomly selected subgroups to answer questions. Comments and explanations were provided by the teacher according to the answers. Additionally, the teacher guided the students to think, discuss, and summarize the knowledge points of the class. When class was almost over, a quiz was conducted to monitor the students' mastery of the lesson. After the seminar, the students were required to finish the homework and summarize the key knowledge points and then submit the learning notes.

\section{Measurements}

\section{Academic performance}

The Medical Nursing assessment contains two parts, the final exam and the process assessment. The maximum total score for the course was 100 . The total score was determined using the weights (Table 1).

The final exam was conducted one week after the course was finished. The total score of the final exam is 100, it consists of 50 multiple choice (50\%), 5 explanation of nouns (15\%), 3 short answer questions (15\%), and 1 case analysis questions (20\%). The examination questions are taken from the question bank of Medical Nursing according to the teaching outline, then reviewed by another two lecturers and finalized by a professor who was the leader of the teaching team. The content validity of the final examination was 0.9 , marked by the two reviewing lectures, and the average difficulty coefficient and discrimination of this paper is about 0.6 and 0.5 , respectively. The Spearman-Brown split-half reliability of the examination questions is 0.76 .

The process assessment included the quizzes, online learning progress (for experimental class) or offline learning notes (for control class), performance and homework. There were 29 times quizzes in total and each quiz comprised ten multiple option questions for each flipped classroom or each seminar. The Spearman-Brown split-half reliability of the quizzes ( 290 questions in total) is 0.79 . Online learning 
progress could be recorded and assessed automatically by the learning platform according to the preset weight coefficient, while offline learning notes and homework are mainly marked by teachers according to the grading criteria. Students' performance was assessed according to their answers in class. The homework consisted of two experiment reports. The average difficulty coefficient of the quiz and homework is 0.7 and 0.5 , respectively. The average difficulty coefficient of homework was assessed according the formula that is 1 minus the ratio of the average score of the homework over the full mark of the homework.

\section{Assessment of the critical thinking ability of students}

The California Critical Thinking Disposition Inventory (CTDI) has been specifically developed and used for nursing students [37]. It has been shown to be a valid instrument for assessing critical thinking ability among nursing students in different cultural contexts [38]. The population included in the present study consisted of Chinese students. Hence, the CTDI-Chinese Version (CTDI-CV), which was translated, modified, and validated by Chinese researchers, was more suitable than the original [39]. The CTDI-CV exhibits a good overall content validity index (0.89) and Cronbach's alpha (0.90), indicating satisfactory content validity and internal consistency, respectively [39].

The CCTDI measures overall critical thinking disposition. There are 70 items in total, and it consists of seven subscales that measure the following dispositions: truth-seeking, open-mindedness, analyticity, systematicity, critical thinking self-confidence, inquisitiveness, and cognitive maturity. Items are scored with a 6-point Likert scale: $1=$ strongly disagree to $6=$ strongly agree, with a maximum total score of 420 . The internal reliability coefficients (Cronbach's alpha) in our study were 0.86 (pretest) and 0.87 (posttest), and the values for the subscales ranged from 0.73 to 0.82 .

\section{Ethical considerations}

Approval was obtained from the Research Ethics Committee of Fujian Medical University. The participants were informed that they had the right not to participate and could withdraw from the study at any time. Written informed consent was obtained from all students who agreed to participate in the study. We informed the participants of the purpose, content, and extent of the study, and guaranteed that their responses were confidential.

\section{Data collection procedure}

The students in the two classes completed the questionnaire prior to and following the teaching experiment. The data collection procedure was explained to all participants, and information regarding the estimated time and number of contacts with participants was provided. Students who agreed to participate in the study were asked to provide demographic data and outcome data (critical thinking assessment) in a pretest assessment conducted during the meeting in which they were enrolled in the study. Outcome variables were measured again 1 school year after the intervention, as a posttest assessment. Additionally, we collected the final course grades of the participants. The data collection 
procedure primarily relied on a descriptive, noninvasive questionnaire on each student's demographic characteristics and critical thinking ability.

\section{Data analysis}

All statistical analyses were conducted using Statistical Package for the Social Sciences (SPSS), version 22.0 (IBM Corp., Armonk, NY, USA). Mean and standard deviation were used to represent the normally distributed continuous data, while median $(M)$ and quartiles $\left(P_{25}-P_{75}\right)$ were used to represent the nonnormally distributed continuous data. A Shapiro-Wilk test was first performed to verify the normal distribution of the academic performance data, and the Mann-Whitney $U$ test was subsequently used. We used the two-tailed approach for the unpaired $t$ test. In addition, ANCOVA analyses that were controlled for academic performance in seven professional basic courses in the previous academic year as confounders were performed to examine the effect on academic performance in Medical Nursing. ANCOVA analyses was also performed to examine the two teaching methods' effect on critical thinking. The significance level was set at $\mathrm{p} \otimes 0.05$.

\section{Results}

\section{Characteristics of participants}

The main features of undergraduate nursing curricula in Fujian Medical University are shown in an additional file [Additional file 1: Table S1]. Among the 295 nursing students who participated in the study, 260(88.1\%) were females with 141 in the experiment class and 119 in the control class, while 35(11.9\%) were males with 23 in the experiment class and 12 in the control class. The "Chi-square" test showed that the subjects in both experimental and control classes were homogenous in terms of sex. The mean age in the experimental class $(20.13 \pm 0.88)$ and in the control group (19.95 \pm 0.81$)$ was not significantly different $(p=0.080)$. Prior to starting the Medical Nursing course, 295 students completed the CTDI-CV questionnaire. Baseline scores of the critical thinking ability was not significantly different $(p=0.899)$. Therefore, the two classes were considered homogenous. However, in the second semester, 22 students changed their major to Midwifery, three students changed their major to Public Health, and one student discontinued the course. Consequently, at the end of the Medical Nursing course, 269 students met the inclusion criteria (Figure 1).

\section{Academic performance of participants}

Prior to the initiation of the Medical Nursing course, the students in the control class were significantly superior to those in the experimental class in terms of academic performance regarding the seven Professional Basic courses ( $p<0.05$, Table 2). After the 1-year Medical Nursing course, there was no significant difference in the academic performance between the two classes (median $\left(P_{25}-P_{75}\right)$ scores of 81 (77-85) and 80 (76-84) in the experimental and control classes, respectively; $p=0.112$ ). After adjusting covariates of academic performance in the seven professional basic courses in the previous academic 
year, the analysis of covariance showed that the academic performance in the experimental class was higher than the control class $(p<0.001$, Table 3$)$.

\section{Critical thinking ability of participants}

Compared with the control class, the pre-post difference in competency in critical thinking self-confidence in the experimental class was significantly greater $(p=0.037)$. There were no significant differences in other variables related to critical thinking ability between the two classes, either prior to or after the course. In the experimental class, the score of the critical thinking self-confidence dimension was significantly improved while in the control class, there were significant improvements in the total CTDI-CV score and two of the seven dimensions: truth-seeking and systematicity (Table 4).

\section{Discussion}

The results of this study showed that the academic performance of students in the experimental class (blended case-centered learning) was higher than the performance academic of students in the control class (offline case-centered learning) $(p<0.001)$. This finding is in line with similar results regarding the effects of blended learning on academic performance [40].

Also, the results showed that there was significant difference in critical thinking self-confidence in the experimental class, compared with the control class (Table 4). And no significant differences were found in other variables related to critical thinking ability between the two classes, either prior to or after the course. However, both of the two classes slightly improved the critical thinking ability. These results are consistent with those of other studies conducted among nursing students, showing improvements in critical thinking skills based on effective teaching methods [36, 37, 41, 42]. Notably, blended casecentered learning focused on the subject status of the students, and provided the students with opportunities to express themselves in class. Students who expressed their ideas in the process of learning and discussion gained recognition from teachers and classmates, thereby enhancing their confidence and increasing their willingness to express themselves in subsequent classes. It is difficult to increase students' overall critical thinking ability in a relatively short period of time because Chinese basic education system from primary to high school was exam oriented in the past decades, which leads to students paying a lot of attention to exam skills but ignores the cultivation of creativity, critical thinking, etc.

In this study, offline case-centered learning led to improvements in two CTDI-CV dimensions of truthseeking and systematicity. Offline case-centered learning focused on holistic learning with 74 teaching hours in teacher-lead lectures and 44 teaching hours for group seminars. In the group seminars, the discussion was under the teachers' guidance, thus, students can discuss more deeply and systematic. Thus, the systematicity of students was improved by the offline case-centered learning. A previous study supported the use of scientific discussions as beneficial educational tools to develop critical thinking [43]. Further studies should assess the discussion strategies used in blended learning. 
In summary, the findings of our study imply that the blended case-centered learning showed promising results for promoting students' academic performance. Optimization of the teaching design in future studies is vital to explore the effects of blended learning among undergraduate nursing students.

\section{Limitation}

There were certain limitations in this study. First, the participants were recruited from a single university in China, possibly limiting the generalizability of our findings. Second, the study was conducted for only two semesters in one subject, which may limit the validity and reliability of the findings regarding the promotion of critical thinking. Thus, studies assessing the effectiveness of blended learning in other nursing subjects are necessary. Third, we did not interview students regarding their feelings and experiences. Therefore, qualitative research is also warranted. Moreover, it would be useful to follow up the students in this study by evaluating their performance in clinical practice.

\section{Conclusions}

The results confirmed the promising results for promoting students' academic performance by the application of the blended case-centered learning. Both the blended and offline case-centered learning in this study were a suitable educational approach to improve the critical thinking ability of undergraduate nursing students. In the future, blended and offline case-centered learning could be implemented in other nursing subjects.

\section{Declarations}

\section{Ethics approval and consent to participate}

Ethical approval was granted by the Education Department of Fujian Medical University (reference number: +86-0591-22862100). Students were informed regarding the study and signed consent forms.

\section{Consent for publication}

Not applicable

\section{Availability of data and materials}

The dataset used during the study is available from the corresponding author on reasonable request.

\section{Competing interests}

The authors declare that they have no competing interests.

\section{Funding}


This study was supported by the program of Research of Medical Education in 2018, Medical Education Branch of the Chinese Medical Association and Medical Education Committee of the Chinese Society of Higher Education (2018A-N18033), Beijing, China. The two sponsors had no role in the design of the study or collection, analysis, and interpretation of data; writing of the report; or the decision to submit the article for publication.

\section{Authors' contributions}

$\mathrm{RH}$ designed the study, wrote the application for ethical approval, supervised the intervention, data collection and analysis, and critically revised the manuscript. $Y Z$ undertake statistical analysis and wrote the manuscript. All authors made contributions to the design of teaching. SL, ZJ, CY and CM participated in the coordination of the study. LY contributed to the data collection. All authors approved the final manuscript for submission and have agreed to be accountable for the accuracy and integrity of the work.

\section{Acknowledgements}

We thank Mei-Ci Peng, who provided the Chinese version of the California Critical Thinking Disposition Inventory questionnaire for this study. Additionally, we thank all the participants.

\section{Abbreviations}

CTDI-CV: Critical Thinking Disposition Inventory-Chinese Version; CBL: case-based learning; ANOVA: Analysis of variance

\section{References}

1. Simpson E, Courtney M. Critical thinking in nursing education: literature review. Int J Nurs Pract. 2002;8:89-98.

2. Kong LN, Qin B, Zhou YQ, Mou SY, Gao HM. The effectiveness of problem-based learning on development of nursing students' critical thinking: a systematic review and meta-analysis. Int J Nurs Stud. 2014;51(3):458-469.

3. Chang MJ, Chang YJ, Kuo SH, Yang YH, Chou FH. Relationships between critical thinking ability and nursing competence in clinical nurses. J Clin Nurs. 2011;20(21-22):3224-32.

4. Papathanasiou IV, Kleisiaris CF, Fradelos EC, Kakou K, Kourkouta L. Critical thinking: the development of an essential skill for nursing students. Acta Inform Med. 2014;22(4):283-6.

5. Sommers CL. Measurement of critical thinking, clinical reasoning, and clinical judgment in culturally diverse nursing students - a literature review. Nurse Educ Pract. 2018;30:91-100.

6. Carley A. Using technology to enhance nurse practitioner student engagement. Nurse Pract. 2015;40(7):47-54.

7. Kaddoura MA. Critical thinking skills of nursing students in lecture-based teaching and case-based learning. Int J Scholarship of Teaching and Learning. 2011;5(2):1-18. 
8. Thistlethwaite JE, Davies D, Ekeocha S, Kidd JM, MacDougall C, Matthews P, et al. The effectiveness of case-based learning in health professional education. A BEME systematic review: BEME Guide No. 23. Med Teach. 2012;34(6):e421-44.

9. McLean SF. Case-based learning and its application in medical and health-care fields: a review of worldwide literature. J Med Educ Curric Dev. 2016;27:3.

10. Kantar LD, Massouh A. Case-based learning: What traditional curricula fail to teach. Nurse Educ Today. 2015;35(8):e8-14.

11. Gholami M, Saki M, Toulabi T, Kordestani Moghadam P, Hossein Pour AH, Dostizadeh R. Iranian nursing students' experiences of case-based learning: a qualitative study. J Prof Nurs. 2017;33(3):241-9.

12. Hofsten A, Gustafsson C, Haggstrom E. Case seminars open doors to deeper understanding - Nursing students' experiences of learning. Nurse Educ Today. 2010;30(6):533-8.

13. Majeed F. Effectiveness of case-based teaching of physiology for nursing students. Journal of Taibah University Medical Sciences. 2014;9(4):289-92.

14. Yoo MS, Park HR. Effects of case-based learning on communication skills, problem-solving ability, and learning motivation in nursing students. Nurs Health Sci. 2015;17(2):166-72.

15. Yoo MS, Park JH. Effect of case-based learning on the development of graduate nurses' problemsolving ability. Nurse Educ Today. 2014;34(1):47-51.

16. Lichvar AB, Hedges A, Benedict NJ, Donihi AC. Combination of a flipped classroom format and a virtual patient case to enhance active learning in a Required Therapeutics Course. Am J Pharm Educ. 2016;80(10):175.

17. Hsu SD, Chen CJ, Chang WK, Hu YJ.An Investigation of the outcomes of PGY students' cognition of and persistent behavior in learning through the intervention of the flipped classroom in Taiwan. Plos One. 2016; 11(12):e0167598.

18. Liebert CA, Lin DT, Mazer LM, Bereknyei S, Lau JN. Effectiveness of the surgery core clerkship flipped classroom: a prospective cohort trial. Am J Surg. 2016;211(2):451-457.e451.

19. Huang HM, Cheng SF. Application of flipped classroom teaching strategy in nursing education (Article in Chinese). The journal of nursing. 2018;65(6):5-12.

20. Geist MJ, Larimore D, Rawiszer H, Sager AWA. Flipped versus traditional instruction and achievement in a baccalaureate nursing pharmacology course. Nurs Educ Perspect. 2015;36(2):114-115.

21. Lee MK, Park BK. Effects of flipped learning using online materials in a surgical sursing practicum: a pilot stratified group-randomized trial. Healthcare informatics research 2018;24(1):69-78.

22. Harmon RB, Hills RL. Transforming psychiatric mental health nursing education with team based learning. Arch Psychiatr Nurs. 2015;29(6):413-418.

23. Simpson V, Richards E. Flipping the classroom to teach population health: increasing the relevance. Nurse Educ Pract. 2015;15(3):162-167. 
24. Hu R, Gao H, Ye Y, Ni Z, Jiang N, Jiang X. Effectiveness of flipped classrooms in Chinese baccalaureate nursing education: A meta-analysis of randomized controlled trials. Int J Nurs Stud. 2018;79:94-103.

25. Park JY, Woo CH, Yoo JY. Effects of blended cardiopulmonary resuscitation and defibrillation Elearning on nursing students' self-efficacy, problem solving, and psychomotor pkills. Comput Inform Nurs. 2016;34(6):272-80.

26. Garrison DR, Kanuka H. Blended learning: Uncovering its transformative potential in higher education. The Internet and Higher Education. 2004; 7(2):95-105.

27. Walker S, Dwyer T, Moxham L, Broadbent M, Sander T. Facilitator versus preceptor: which offers the best support to undergraduate nursing students? Nurse Educ Today. 2013;33(5):530-5.

28. Pereira JA, Pleguezuelos E, Meri A, Molina-Ros A, Molina-Tomas MC, Masdeu C. Effectiveness of using blended learning strategies for teaching and learning human anatomy. Med Educ. 2007;41(2):189-95.

29. Ireland J, Johnson N, Adams D, Eboh W, Mowatt E. Blended learning in education: effects on knowledge and attitude. Br J Nurs. 2009;18(2):124-30.

30. Hsu L, Hsieh S. Effects of a blended learning module on self-reported learning performances in baccalaureate nursing students. J Adv Nurs. 2011;67(11):2435-44.

31. Gagnon MP, Gagnon J, Desmartis M, Njoya M. The impact of blended teaching on knowledge, satisfaction, and self-directed learning in nursing undergraduates: a randomized, controlled trial. Nurs Educ Perspect. 2013;34(6):377-82.

32. Shorey S, Kowitlawakul Y, Devi MK, Chen HC, Soong SKA, Ang E. Blended learning pedagogy designed for communication module among undergraduate nursing students: a quasi-experimental study. Nurse Educ Today. 2018;61:120-6.

33. Coyne E, Rands H, Frommolt V, Kain V, Plugge M, Mitchell M. Investigation of blended learning video resources to teach health students clinical skills: an integrative review. Nurse Educ Today. 2018;63:101-7.

34. McCutcheon K, O'Halloran P, Lohan M. Online learning versus blended learning of clinical supervisee skills with pre-registration nursing students: a randomised controlled trial. Int J Nurs Stud. 2018;82:30-9.

35. Zolfaghari M, Negarandeh R, Eybpoosh S. Developing a blended learning program for nursing and midwifery students in Iran: Process and preliminary outcomes. Iran J Nurs Midwifery Res. 2013;18(1):20-6.

36. Carter AG, Creedy DK, Sidebotham M. Efficacy of teaching methods used to develop critical thinking in nursing and midwifery undergraduate students: a systematic review of the literature. Nurse Educ Today. 2016;40:209-18.

37. Fero LJ, O'Donnell JM, Zullo TG, Dabbs AD, Kitutu J, Samosky JT, et al. Critical thinking skills in nursing students: comparison of simulation-based performance with metrics. J Adv Nurs. 2010;66(10):2182-93. 
38. Yeh ML. Assessing the reliability and validity of the Chinese version of the California Critical Thinking Disposition Inventory. Int J Nurs Stud. 2002;39(2):123-32.

39. Peng M, Wang G, Chen J, Chen M, Bai H, Li S, et.al. Validity and reliability of the Chinese critical thinking disposition inventory (Article in Chinese). Chinese J Nurs. 2004;39(9):644-7.

40. Kiviniemi MT. Effects of a blended learning approach on student outcomes in a graduate-level public health course. BMC Med Educ. 2014;14:47.

41. Gyeong JA, Myung SY. Critical thinking and learning styles of nursing students at the Baccalaureate nursing program in Korea. Contemp Nurse. 2008;29(1):100-9.

42. Hong S, Yu P. Comparison of the effectiveness of two styles of case-based learning implemented in lectures for developing nursing students' critical thinking ability: a randomized controlled trial. Int J Nurs Stud. 2017;68:16-24.

43. Borglin G, Fagerstrom C. Nursing students' understanding of critical thinking and appraisal and academic writing: a descriptive, qualitative study. Nurse Educ Pract. 2012;12(6):356-60.

\section{Tables}

Table 1 Teaching strategies and evaluation for Medical Nursing between two classes 


\begin{tabular}{|c|c|c|}
\hline & Experimental class & Control class \\
\hline$\overline{\lg }$ & Blended case-centered learning & Case-centered learning \\
\hline \multirow{5}{*}{$\begin{array}{l}\text { ig } \\
\text { es } \\
\text { ng }\end{array}$} & $\begin{array}{l}\text { 1. Online learning and group case } \\
\text { study(43h) }\end{array}$ & 1. Face to face lectures in class $(74 \mathrm{~h})$ \\
\hline & 2. Face to face lectures in class (26h) & \\
\hline & 3. Offline flipped classroom(49h) & 2. Seminar in groups $(44 \mathrm{~h})$ \\
\hline & 4. Laboratory teaching (11h) & 3. Laboratory teaching (11h) \\
\hline & 5. Clinical practice(15h) & 4. Clinical practice(15h) \\
\hline \multirow[t]{10}{*}{ ion } & 1. Academic performance & 1. Academic performance \\
\hline & (1) Final exam, 50\% & (1) Final exam, 50\% \\
\hline & (2) Process assessment, $50 \%$ & (2) Process assessment, 50\% \\
\hline & a. Quiz in the flipped classrooms, & a. Quiz in seminars, $20 \%$; \\
\hline & $20 \%$; & b. Offline learning notes, $15 \%$; \\
\hline & b. Online learning progress & c. Performance in seminars, $10 \%$; \\
\hline & requirements, $15 \%$; & d. Homework, 5\% \\
\hline & $\begin{array}{l}\text { c. Performance in the flipped } \\
\text { classrooms, } 10 \% \text {; } \\
\text { d. Homework. } 5 \%\end{array}$ & \\
\hline & 2. Critical Thinking Disposition & 2. Critical Thinking Disposition \\
\hline & Inventory-Chinese Version & Inventory-Chinese Version \\
\hline
\end{tabular}

*One teaching hour equal to 40 minutes

Table 2 Comparison of academic performance in the Professional Basic courses in the previous academic year 


\begin{tabular}{|c|c|c|c|c|c|c|}
\hline \multirow{2}{*}{$\begin{array}{l}\text { [ } \\
\end{array}$} & \multicolumn{5}{|c|}{ Experimental group $(n=151) \quad$ Control group $(n=118)$} & \multirow[b]{2}{*}{$P$ value } \\
\hline & $\begin{array}{l}\text { Median }\left(\mathrm{P}_{25^{-}}\right. \\
\left.\mathrm{P}_{75}\right)\end{array}$ & Mean \pm SD & $\begin{array}{l}\text { Median }\left(\mathrm{P}_{25}-\right. \\
\left.\mathrm{P}_{75}\right)\end{array}$ & Mean \pm SD & $\begin{array}{l}\mathrm{z} / \mathrm{t} \\
\text { value }\end{array}$ & \\
\hline & $66(60-72)$ & $64.83 \pm 10.03$ & $70.5(63-78)$ & $70.38 \pm 9.84$ & 3.878 & $<0.001$ \\
\hline & 67 (61-72) & $66.87 \pm 8.43$ & $71(65-77)$ & $71.36 \pm 8.30$ & 3.944 & $<0.001$ \\
\hline i to & $64(61-68)$ & $64.58 \pm 5.82$ & $65(62-70)$ & $66.20 \pm 5.86$ & 2.342 & 0.019 \\
\hline \multirow{2}{*}{$\begin{array}{l}\text { nd } \\
\operatorname{logy}\end{array}$} & $70(65-75)$ & $69.77 \pm 8.42$ & $75.5(68-82)$ & $75.07 \pm 9.07$ & $-5.008 *$ & $<0.001$ \\
\hline & $70(65-76)$ & $70.13 \pm 8.23$ & $73(68-78)$ & $72.69 \pm 9.26$ & 2.694 & 0.007 \\
\hline \multirow{4}{*}{ gy } & & & & & & \\
\hline & 71 (64-77) & $69.59 \pm 9.96$ & $75(68-81)$ & $73.79 \pm 10.14$ & 3.248 & 0.001 \\
\hline & $74(70-78)$ & $73.57 \pm 6.71$ & $78(74-83)$ & $77.25 \pm 7.11$ & 4.607 & $<0.001$ \\
\hline & & $80.95 \pm 6.19$ & & $79.53 \pm 6.74$ & & \\
\hline
\end{tabular}

*correspond to t value

Table 3 Differences in academic performance in professional basic courses and Medical Nursing between experimental and control classes 


\begin{tabular}{|c|c|c|c|c|}
\hline lent variable & $\begin{array}{l}\text { Experimental } \\
\text { class }(n=151) \\
\text { Mean } \pm \text { SD }\end{array}$ & $\begin{array}{l}\text { Control } \\
\text { class }(n=118) \\
\text { Mean } \pm \text { SD }\end{array}$ & $\mathrm{F}$ & $\begin{array}{l}\mathrm{P} \\
\text { value }\end{array}$ \\
\hline $\begin{array}{l}\text { (covariate) } \\
\text { Nursing }\end{array}$ & $\begin{array}{l}64.83 \pm 10.03 \\
82.03 \pm 0.39\end{array}$ & $\begin{array}{l}70.38 \pm 9.84 \\
78.15 \pm 0.44\end{array}$ & 41.87 & $<0.001$ \\
\hline $\begin{array}{l}\text { gy (covariate) } \\
\text { Nursing }\end{array}$ & $\begin{array}{l}66.87 \pm 8.43 \\
81.85 \pm 0.43\end{array}$ & $\begin{array}{l}71.36 \pm 8.30 \\
78.38 \pm 0.48\end{array}$ & 28.19 & $<0.001$ \\
\hline $\begin{array}{l}\text { tion to } \\
\text { Sciences(covariate) } \\
\text { Nursing }\end{array}$ & $\begin{array}{l}64.58 \pm 5.82 \\
81.39 \pm 0.44\end{array}$ & $\begin{array}{l}66.20 \pm 5.86 \\
78.98 \pm 0.50\end{array}$ & 13.12 & $<0.001$ \\
\hline $\begin{array}{l}\text { Iy and } \\
\text { ysiology(covariate) } \\
\text { Nursing }\end{array}$ & $\begin{array}{l}69.77 \pm 8.42 \\
82.15 \pm 0.39\end{array}$ & $\begin{array}{l}75.07 \pm 9.07 \\
78.00 \pm 0.44\end{array}$ & 48.31 & $<0.001$ \\
\hline $\begin{array}{l}\text { nic Biology } \\
\text { tunology(covariate) } \\
\text { Nursing }\end{array}$ & $\begin{array}{l}70.13 \pm 8.23 \\
81.53 \pm 0.38\end{array}$ & $\begin{array}{l}72.69 \pm 9.26 \\
78.78 \pm 0.43\end{array}$ & 22.90 & $<0.001$ \\
\hline $\begin{array}{l}\text { zology(covariate) } \\
\text { Nursing }\end{array}$ & $\begin{array}{l}69.59 \pm 9.96 \\
81.83 \pm 0.36\end{array}$ & $\begin{array}{l}3.79 \pm 10.14 \\
78.41 \pm 0.40\end{array}$ & 39.48 & $<0.001$ \\
\hline $\begin{array}{l}\text { ssessment(covariate) } \\
\text { Nursing }\end{array}$ & $\begin{array}{l}73.57 \pm 6.71 \\
82.03 \pm 0.37\end{array}$ & $\begin{array}{l}77.25 \pm 7.11 \\
78.15 \pm 0.42\end{array}$ & 45.49 & $<0.001$ \\
\hline
\end{tabular}

Table 4 Values of the variables measured before and after the intervention: between both classes and intra-class variability 


\begin{tabular}{|c|c|c|c|c|}
\hline ependent variable & $\begin{array}{l}\text { Experimental } \\
\text { class } \\
\text { Mean } \pm \text { SD }\end{array}$ & $\begin{array}{l}\text { Control class } \\
\text { Mean } \pm \text { SD }\end{array}$ & $\mathrm{F}$ & $\begin{array}{l}\text { P value } \\
\text { (inter- } \\
\text { class) }\end{array}$ \\
\hline $\begin{array}{l}\text { tical Thinking (Total) } \\
\text { 'retest } \\
\text { 'osttest }\end{array}$ & $\begin{array}{l}273.54 \pm 18.36 \\
276.17 \pm 23.00\end{array}$ & $\begin{array}{l}273.73 \pm 18.83 \\
279.30 \pm 19.24\end{array}$ & $\begin{array}{l}0.006 \\
1.625\end{array}$ & $\begin{array}{l}0.937 \\
0.203\end{array}$ \\
\hline$i$ & 1.352 & 4.821 & & \\
\hline ' value (intra-class) & 0.245 & 0.029 & & \\
\hline $\begin{array}{l}\text { lth-seeking } \\
\text { 'retest } \\
\text { 'osttest }\end{array}$ & $\begin{array}{l}36.89 \pm 4.27 \\
37.23 \pm 5.68\end{array}$ & $\begin{array}{l}36.51 \pm 4.27 \\
37.82 \pm 3.81\end{array}$ & $\begin{array}{l}0.489 \\
1.495\end{array}$ & $\begin{array}{l}0.484 \\
0.222\end{array}$ \\
\hline ' value (intra-class) & $\begin{array}{l}0.433 \\
0.511\end{array}$ & $\begin{array}{l}5.836 \\
0.016\end{array}$ & & \\
\hline $\begin{array}{l}\text { en-mindedness } \\
\text { 'retest } \\
\text { 'osttest }\end{array}$ & $\begin{array}{l}40.25 \pm 0.33 \\
40.61 \pm 0.34\end{array}$ & $\begin{array}{l}40.81 \pm 0.36 \\
41.14 \pm 0.38\end{array}$ & $\begin{array}{l}1.307 \\
1.096\end{array}$ & $\begin{array}{l}0.253 \\
0.296\end{array}$ \\
\hline ' value (intra-class) & $\begin{array}{l}0.581 \\
0.446\end{array}$ & $\begin{array}{l}0.403 \\
0.526\end{array}$ & & \\
\hline $\begin{array}{l}\text { alyticity } \\
\text { 'retest } \\
\text { 'osttest }\end{array}$ & $\begin{array}{l}40.63 \pm 0.31 \\
41.05 \pm 0.32\end{array}$ & $\begin{array}{l}40.91 \pm 0.34 \\
41.77 \pm 0.36\end{array}$ & $\begin{array}{l}0.361 \\
2.265\end{array}$ & $\begin{array}{l}0.548 \\
0.133\end{array}$ \\
\hline ' value (intra-class) & $\begin{array}{l}0.876 \\
0.350\end{array}$ & $\begin{array}{l}3.007 \\
0.083\end{array}$ & & \\
\hline $\begin{array}{l}\text { stematicity } \\
\text { 'retest } \\
\text { 'osttest }\end{array}$ & $\begin{array}{l}37.03 \pm 0.29 \\
37.72 \pm 0.30\end{array}$ & $\begin{array}{l}36.94 \pm 0.32 \\
38.26 \pm 0.34\end{array}$ & $\begin{array}{l}0.038 \\
1.444\end{array}$ & $\begin{array}{l}0.845 \\
0.230\end{array}$ \\
\hline ' value (intra-class) & $\begin{array}{l}2.791 \\
0.095\end{array}$ & $\begin{array}{l}8.014 \\
0.005\end{array}$ & & \\
\hline $\begin{array}{l}\text { tical thinking self-confidence } \\
\text { 'retest } \\
\text { 'osttest }\end{array}$ & $\begin{array}{l}37.42 \pm 0.32 \\
38.48 \pm 0.33\end{array}$ & $\begin{array}{l}36.89 \pm 0.36 \\
37.43 \pm 0.38\end{array}$ & $\begin{array}{l}1.238 \\
4.358\end{array}$ & $\begin{array}{l}0.266 \\
0.037\end{array}$ \\
\hline ' value (intra-class) & $\begin{array}{l}5.507 \\
0.022\end{array}$ & $\begin{array}{l}1.119 \\
0.291\end{array}$ & & \\
\hline $\begin{array}{l}\text { luisitiveness } \\
\text { 'retest } \\
\text { 'osttest }\end{array}$ & $\begin{array}{l}41.65 \pm 0.34 \\
41.60 \pm 0.36\end{array}$ & $\begin{array}{l}41.85 \pm 0.38 \\
42.23 \pm 0.40\end{array}$ & $\begin{array}{l}0.147 \\
1.381\end{array}$ & $\begin{array}{l}0.702 \\
0.240\end{array}$ \\
\hline ' value (intra-class) & $\begin{array}{l}0.012 \\
0.913\end{array}$ & $\begin{array}{l}0.471 \\
0.493\end{array}$ & & \\
\hline $\begin{array}{l}\text { gnitive maturity } \\
\text { 'retest } \\
\text { 'osttest }\end{array}$ & $\begin{array}{l}39.67 \pm 0.36 \\
39.48 \pm 0.37\end{array}$ & $\begin{array}{l}39.82 \pm 0.40 \\
40.53 \pm 0.42\end{array}$ & $\begin{array}{l}0.077 \\
3.517\end{array}$ & $\begin{array}{l}0.782 \\
0.061\end{array}$ \\
\hline 'value (intra-class) & $\begin{array}{l}0.129 \\
0.719 \\
\end{array}$ & $\begin{array}{l}1.536 \\
0.216 \\
\end{array}$ & & \\
\hline
\end{tabular}

\section{Additional File Legends}


Additional file 1: Table S1. The main features of undergraduate nursing curricula in Fujian Medical University in China

\section{Figures}

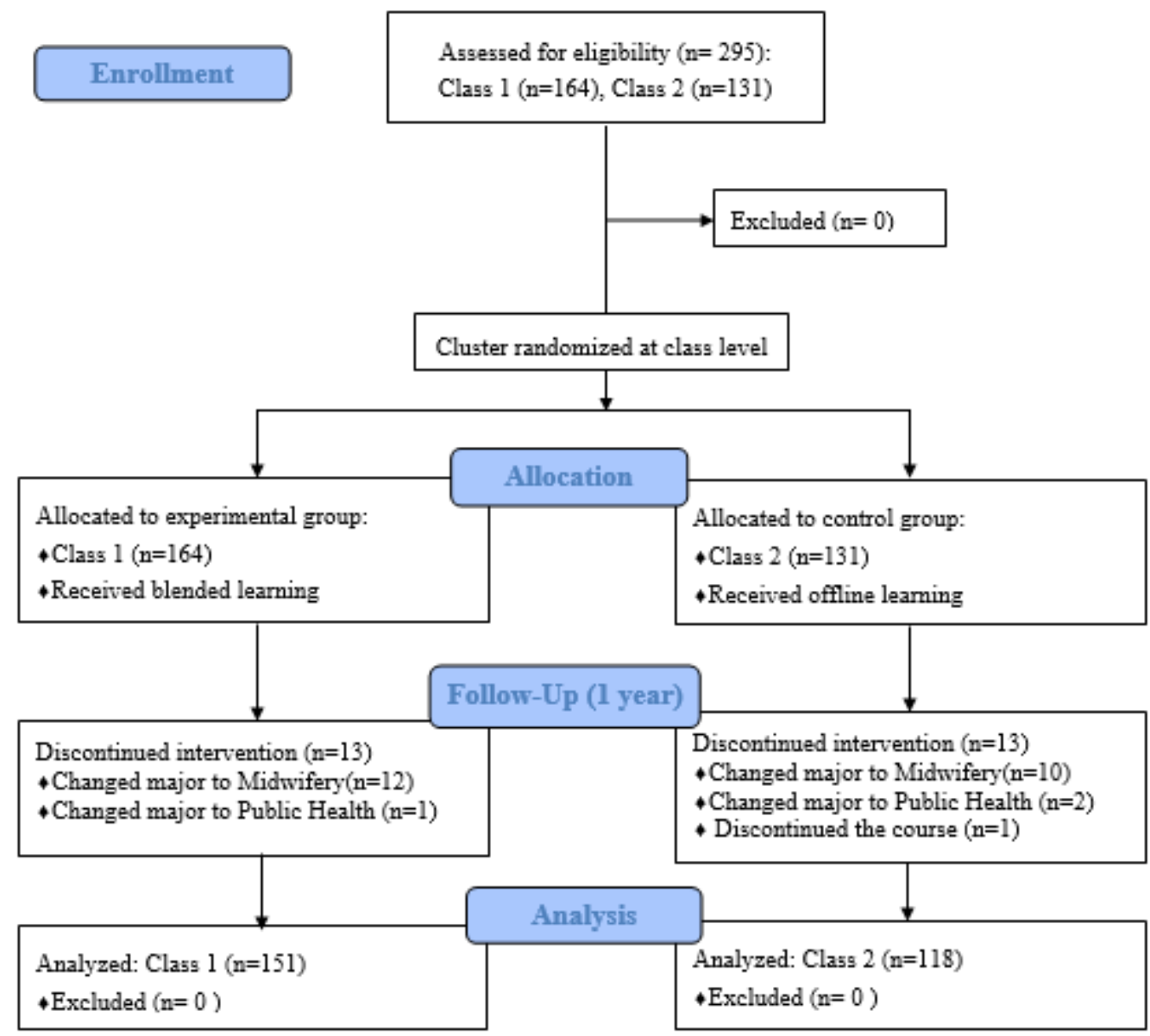

\section{Figure 1}

Participants flow diagram 


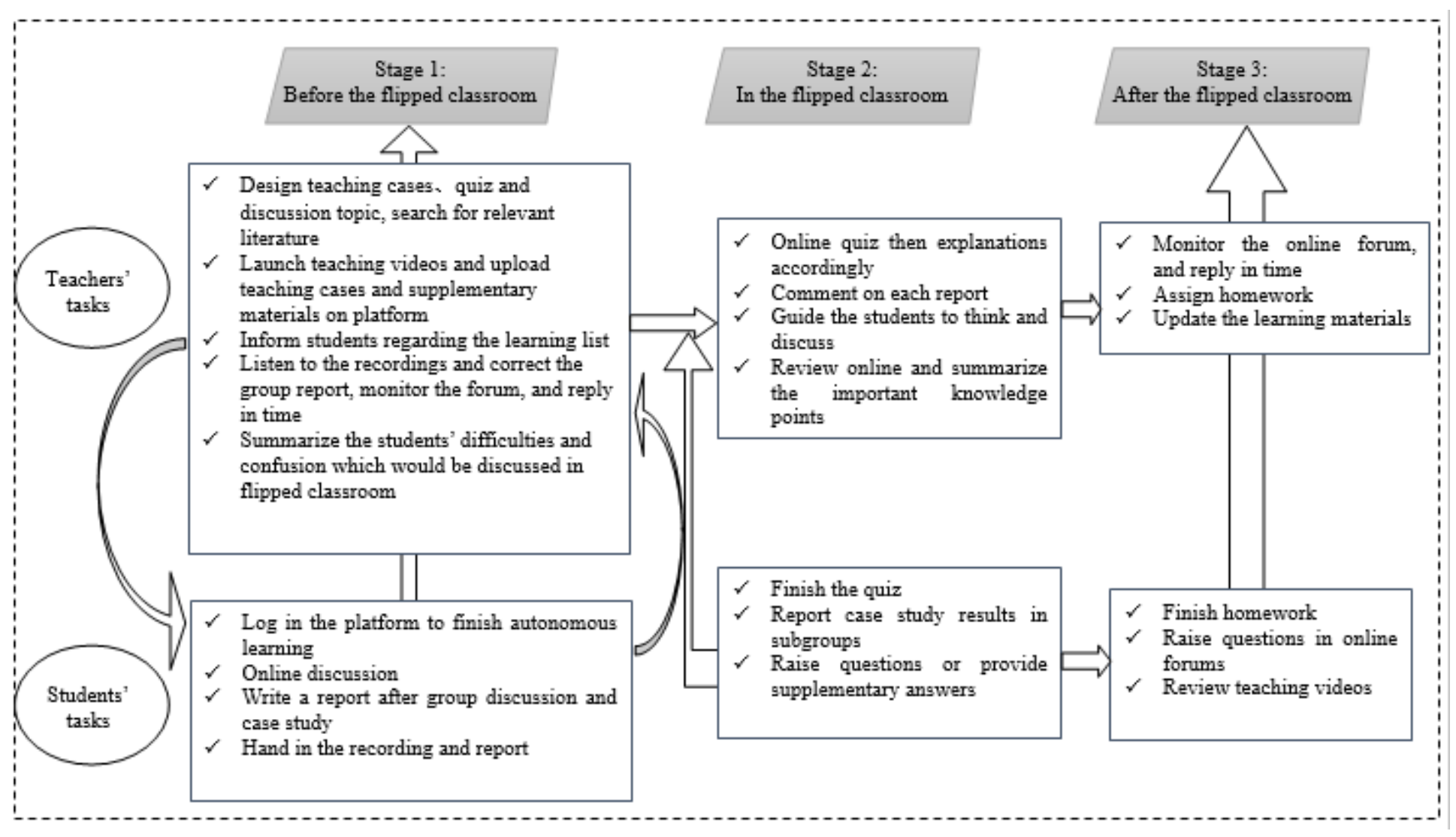

\section{Figure 2}

Blended case-centered learning in the experimental class

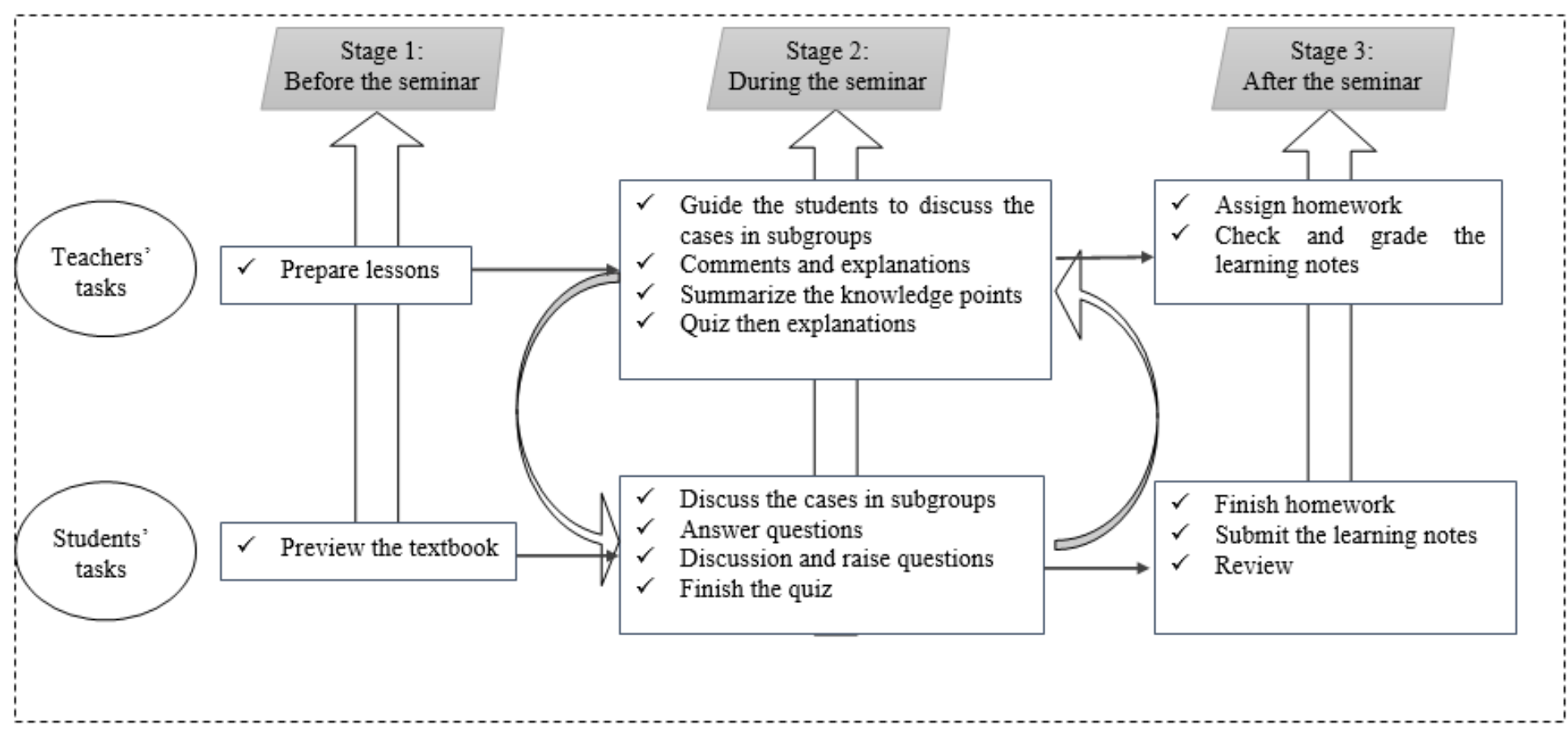

\section{Figure 3}




\section{Supplementary Files}

This is a list of supplementary files associated with this preprint. Click to download.

- 2020.1.30AdditionalFile.pdf 